\title{
STRATEGI BISNIS TEKNOLOGI INFORMASI PADA PERUSAHAAN HITACHI, LTD.
}

\author{
Tri Pudjadi; Achmad Jaya; Defria A. Kiranal; Raedi Rahadian \\ Information Systems Department, School of Information Systems, Binus University \\ Jl. K.H. Syahdan No. 9, Palmerah, Jakarta Barat 11480 \\ tripujadi@binus.edu
}

\begin{abstract}
Information technology (IT) application for corporate is now a very common thing. It brings many benefits, such as improving business performance, minimizing marketing cost and time, and minimizing the risk in doing business. Hitachi, Ltd. relies on information technology for the company's progress. Various IT strategies performed by Hitachi, Ltd. for improving the quality of their business which one of them is implementing enterprise resource planning (ERP) system of Microsoft Dynamics Navision as its core business application. As a business management software, this system connects many components of the organization by presenting a comprehensive business management functionality-from the financial sector to supply chain. Nevertheless, one of the shortcomings of ERP system is its inefficient schedule solution. Therefore, Hitachi, Ltd. implements a lot of strategies, beside ERP, to survive in the competitive business world of information technology.
\end{abstract}

Keywords: information technology, strategy strategy, business, Hitachi,Ltc

\begin{abstract}
ABSTRAK
Teknologi Informasi (TI) membawa banyak manfaat bagi perusahaan, terutama untuk meningkatkan performa bisnis, meminimalisasi biaya dan waktu pemasaran, serta meminimalisasi resiko terhadap bisnis yang dinamis. Sebagai perusahaan yang mengandalkan TI Hitachi, Ltd. berusaha merumuskan berbagai strategi untuk meningkatkan kualitas bisnisnya dengan menggunakan Model enterprise resource planning (ERP) Microsoft Dynamics Navision dalam aplikasi operasi perusahaan. Penelitian bertujuan melakukan evaluasi model bisnis berbasis TI yang dilakukan di perusahaan ini. Metode yang digunakan adalah metode kualitatif, meliputi aktivitas survai dan studi, analisis strategi, dan rancangan model bisnis. Simpulan hasil penelitian adalah penggunaan model tersbut sebagai perangkat lunak manajemen bisnis, dapat menghubungkan komponen penggerak organisasi dengan menghadirkan fungsionalitas manajemen bisnis yang komprehensif, mulai dari sektor keuangan hingga rantai suplai. Namun, salah satu kekurangan dari sistem ERP adalah solusi penjadwal kerja yang tidak efisien. Maka dari itu, Hitachi, Ltd. melakukan berbagai strategi bisnis teknologi informasi untuk bertahan dalam persaingan dunia bisnis teknologi informasi.
\end{abstract}

Kata kunci: strategi, teknologi informasi, bisnis, Hitachi, Ltd. 


\section{PENDAHULUAN}

Teknologi informasi (TI) secara potensial merupakan suatu strategi, seperti yang dikemukakan oleh Michael Porter (1998)," a leading scholar of competitive strategy, asserts that the power of technology as competitive variables lies in its ability to alter competition through changing industry structure". Pernyataan Porter ini mengandung arti bahwa kekuatan teknologi merupakan suatu gambaran dari strategi kompetitif perusahaan yang artinya adalah dapat disebut sebagai salah satu variabel kompetitif yang dapat mengindikasikan kemampuan berkompetisi melalui perubahan struktur industri.

Di antara perusahaan besar dunia yang menjadikan Teknologi Informasi menjadi bagian terpenting untuk kemajuan perusahaan adalah Hitachi, Ltd. Sebagai penyedia terkemuka produk penggunaan pribadi dan bisnis, Hitachi, Ltd. menggunakan Job Management Partner 1/Automatic Job Management System Hitachi (JP1/AJS Hitachi) untuk meningkatkan efisiensi manajemen pekerjaan, mempertajam akurasi data, serta mengurangi beban kerja administratif tim TI dan pengguna akhirnya. Hitachi, Ltd. Juga menerapkan sistem informasi lainnya sebagai pendukung utama di perusahaan.

Penelitian bertujuan mempelajari berbagai hal yang terkait dengan: (1) bagaimana dampak dari penggunaan TI pada perusahaan Hitachi, Ltd.; (2) strategi bisnis dan TI yang telah dipakai oleh perusahaan Hitachi, Ltd. dalam mempertahankan ancaman persaingan bisnis; (3) keberhasilan dari penerapan ERP dan JP1/AJS Hitachi, Ltd. yang di perusahaan ini.

Pencapaian keberhasilan perusahaan Hitachi, Ltd. tidak luput dari sistem informasi yang membantu proses berjalannya perusahaan tersebut. Dalam hal ini perusahaan memiliki business model yang sangat teratur, memiliki strategi bisnis yang sangat memukau, dan tentunya memiliki Teknologi Informasi yang menjadikan perusahaan semakin terdepan dan maju.

Sebuah bisnis model menurut Casadesus-Masanell dan Ricart (2009) menggambarkan konten, struktur dan kelayakan aliran transaksi dalam perusahaan sebagai upayanya menghasilkan nilai bisnis melalui eksploitasi peluang yang ada. Baden-Fuller (2002) mendefinisikan sebuah business model sebagai logika proses bisnis perusahaan, cara bagaimana perusahaan beroperasi dan bagaimana manghasilkan value untuk para stakeholders.

Strategi bisnis adalah strategi yang berorientasi pada fungsi-fungsi kegiatan manajemen, misalnya strategi pemasaran, strategi produksi atau operasional, strategi distribusi, strategi organisasi dan strategi-strategi yang berhubungan dengan keuangan (Rangkuti, 2000). Strategi TI adalah strategi yang berfokus pada penetapan visi tentang bagaimana teknologi dapat mendukung dalam memenuhi kebutuhan informasi dan sistem dari sebuah organisasi (Ward dan Peppard, 2002, p44). Sedangkan strategi SI adalah strategi yang mendefinisikan kebutuhan organisasi atau perusahaan terhadap informasi dan sistem yang mendukung keseluruhan strategi bisnis yang dimiliki organisasi tersebut. Hal ini dihubungkan dengan konteks bisnis dengan mempertimbangkan dampak persaingan dalam bisnis dan kebutuhan perusahaan terhadap teknologi informasi atau sistem informasi.

Keterkaitan antara strategi teknologi informasi (TI), sistem informasi(SI) dengan strategi bisnis mendorong Hitachi, Ltd. mengutamakan elemen-elemen tersebut untuk menjadi bagian dari visi misi yang menjadi landasan keberhasilan sebuah perusahaan Hitachi, Ltd. Strategi yang mengandalkan teknologi infromasi tersebut memberikan dampak yang besar bagi kemajuan perusahaan Hitachi, Ltd. Tentunya strategi ini menjadikan Hitachi, Ltd. unggul dalam persaingan teknologi informasi.

Salah satu kesulitan yang dialami perusahaan dalam merumuskan rencana strateginya, yaitu menterjemahkan visi perusahaan menjadi pelaksanaan yang nyata (Victor, 2010). Untuk 
mentransformasikan visi perusahaan tersebut diperlukan langkah strategis dan cara implementasi yang tepat. Pemilihan yang benar adalah merupakan konsep inti dalam formulasi strategi. Isu ini banyak dimanfaatkan di perusahaan produksi maupun jasa yang secara efektif merupakan dasar berkembangnya teori supply chain management.

Ward dan Peppard (2002, p47) mengemukakan beberapa alasan yang menyebabkan perlunya sebuah perusahaan memiliki strategi sistem informasi dan teknologi informasi (SI/TI) sbb: (1) investasi pada SI/TI tidak mendukung sasaran bisnis; (2) tidak terkontrolnya SI/T I yang ada; (3) sistem yang tidak terintegrasi, sehingga memungkinkan terjadinya duplikasi data dan hilangnya keterkaitan antar sumber daya informasi; (4) perusahaan tidak memiliki panduan untuk menentukan prioritas proyek SI/TI dan selalu terjadi perubahan sehingga menurunkan produktivitas; (5) manajemen informasi yang buruk dan tidak akurat; (6) strategi SI/TI tidak sejalan dengan strategi bisnis perusahaan; (7) proyek SI/TI hanya dievaluasi pada basis keuangan semata.

\section{METODE}

Untuk mendapatkan hasil dari pembahasan perusahaan Hitachi, Ltd. ini, digunakanlah metode kualitatif. Menurut (Strauss \& Corbin, 2003) Penelitian kualitatif juga bisa dimaksudkansebagai jenis penelitian yang temuan-temuannya tidak diperoleh melalui prosedur. Langkah dalam penelitian yang dilakukan meliputi aktivitas survai dan studi perusahaan untuk mengumpulkan berbagai data dan fakta yang berhubungan dengan masalah yang dibahas. Selanjutnya dilakukan analisis strategi dengan mengacu pada model lima daya Porter, SWOT analysis dan lainnya. Hasilnya ditampilkan dalam sebuah rancangan model bisnis Hitachi,Ltd.

\section{HASIL DAN PEMBAHASAN}

Teknologi Informasi dipastikan merupakan suatu system yang dapat memicu keberhasilan suatu perusahaan yang memberikan banyaknya peluang bisnis bagi perusahaan Hitachi,Ltd. Berbagai macam strategi teknologi informasi bisnis yang dilakukan oleh Hitachi, Ltd. untuk meningkatkan value bisnis dan bertahan di dalam dunia persaingan. Strategi Bisnis berbasis Teknologi Informasi yang dilakukan Hitachi, Ltd. di antaranya adalah: ERP, Hitachi storage data/ data system, dan P1/AJS Hitachi.

\section{ERP}

ERP menurut (O'Brien, 2005) adalah sebuah framework transaksi enterprise yang menghubungkan proses pemesanan barang, manajemen inventarisasi dan kontrol, perencanaan distribusi dan produksi, dan keuangan. ERP bekerja sebagai kekuatan lintas fungsional perusahaan yang mengintegrasikan dan mengautomatisasi berbagai proses bisnis internal dan sistem informasi termasuk manufacturing, logistik, distribusi, akuntansi, keuangan, dan sumber daya manusia dari sebuah perusahaan.

Hitachi Singapore menggunakan sistem Enterprise Resource Planning (ERP) Microsoft Dynamics Navision sebagai sistem aplikasi bisnis untuk kegiatan operasional perusahaan. Sebagai perangkat lunak manajemen bisnis, sistem ini menghubungkan banyak komponen penggerak dari organisasi dengan menghadirkan fungsionalitas manajemen bisnis yang komprehensif- mulai dari sektor keuangan hingga rantai suplai. Namun, salah satu kekurangan dari sistem ERP adalah solusi penjadwal kerjanya yang tidak efisien. 
Tantangan yang dihadapi oleh Hitachi dalam menggunakan sistem ERP Microsoft Dynamics Navision (NAV) adalah: (1) tidak memiliki beberapa fitur penting seperti peringatan sistem dan sajian pekerjaan berbasis peristiwa; (2) waktu proses TI yang substansial yang timbul akibat pemantauan manual sajian pekerjaan; (3) jam kerja yang tidak perlu yang dihabiskan untuk manajemen pekerjaanTingkat risiko kesalahan yang tinggi akibat operasi manual; (4) tingkat risiko kesalahan yang tinggi akibat operasi manual.

Selain kelemahan diatas, sistem ERP dari Microsoft Dynamics NAV tidak memiliki fungsi peringatan untuk memberi tahu staf TI dan end user ketika ada kegagalan eksekusi dalam pengalihan sistem seperti yang sudah direncanakan. Ini adalah rintangan utama yang hanya dapat diatasi dengan secara khusus menugaskan anggota staf TI ke tugas pemantauan pekerjaan. Ini memastikan bahwa pekerjaan Electronic Data Interchange (EDI) tidak menemui masalah apa pun. Namun, ini akan berarti bahwa ketidaknormalan sistem apa pun tidak dapat dideteksi bila tidak ada staf yang memantaunya.

\section{Hitachi Storage Data/ Data System}

Sistem ini memiliki sepuluh tren bisnis storage, yaitu: (1) percepatan adopsi virtualisasi dan dynamic provisioning; (2) integrasi server dan virtualization storage; (3) adopsi virtual tiering untuk ILM; (4) penggunaan media SSD untuk peningkatan kinerja; (5) adopsi Serial Attached SCSI (SAS) untuk storage system kelas enterprise; (6) penggunaan drive small form factor (berukuran 2,5 inci) untuk memaksimalkan efisiensi daya dan kapasitas; (7) adopsi cloud computing; (8) konvergensi data center; (9) penggunaan cloud computing untuk virtualisasi storage dan transparansi aplikasi; (10) transformasi data center lewat remote managed services. Untuk mendukung sepuluh tren ini, strategi bisnis Hitachi Data Systems di Indonesia akan difokuskan pada penyediaan solusi, penerapan virtualisasi, dan mendorong adopsi cloud computing.

\section{P1/AJS Hitachi}

P1/AJS Hitachi menyederhanakan tugas dalam menentukan dan mengoordinasikan pekerjaan, yang dibuat jauh lebih mudah melalui ketersediaan template. Template manajemen informasi penentuan pekerjaan sangat membantu untuk menciptakan, memperbarui, atau menghapus sejumlah besar pekerjaan. Layar perintah yang intuitif memungkinkan kustomisasi pekerjaan dengan mudah sesuai dengan jenis pengguna. Pekerjaan ini dapat termodulasi sesuai dengan tujuan dari pengguna, termasuk menu terpisah dan hak bagi administrator sistem, pengembang, dan operator.

Hitachi menggunakan JP1/AJS Hitachi sebagai salah satu solusi dalam TI nya, Hitachi dapat mengintegrasikan antar bagian sehingga dapat membuat tugas menjadi lebih sederhana terutama dalam menentukan tugas dan mengkoordinasikan pekerjaan antar bagian. Dengan manajemen informasi penentuan pekerjaan sangat membantu untuk menciptakan, memperbarui, atau menghapus sejumlah besar pekerjaan. Dengan sistem TI maka pekerjaan dapat termodulasi sesuai dengan tujuan dari pengguna, termasuk menu terpisah bagi administrator sistem, pengembang, dan operator.

Fitur otomatis dari sistem penjadwalan pekerjaan telah menurunkan risiko kesalahan manusia secara dramatis. Misalnya, pembaruan secara teratur daftar biaya material ( bill of material ) telah menghasilkan hal yang baik bagi perusahaan, selain itu dengan penggunaan TI ini dapat mengurangi jumlah jam kerja dari pekerjaan yang dilakukan secara manual oleh staf TI dan end user. Kondisi pencarian canggih yang disediakan dengan rangkaian fitur meningkatkan efisiensi tim TI Hitachi. Hal ini karena adanya kemampuan pencarian dari software yang ada sehingga memungkinkan para staf menemukan sesuatu dengan cepat.

Dengan penggunaan TI untuk internal sekaligus produsen TI yang dipakai perusahaanperusahaan besar, Hitachi dapat menciptakan hubungan yang baik dengan para pelanggan dan calon 
pelanggannya. Seperti yang telah diungkap diatas, dengan penggunaan TI, Hitachi dapat mengintegrasikan seluruh bagian sehingga mempermudah dalam koordinasi dan mempercepat sistem produksi yang dapat membuat hubungan eksternal menjadi lebih baik. Apabila dilihat dari sisi produsen TI, bagi hubungan eksternal Hitachi merupakan salah satu solusi yang dapat digunakan sebagai penyedia jasa TI yang lengkap. Model Topologi TI Hitachi, Ltd. ditampilkan pada Gambar 1.

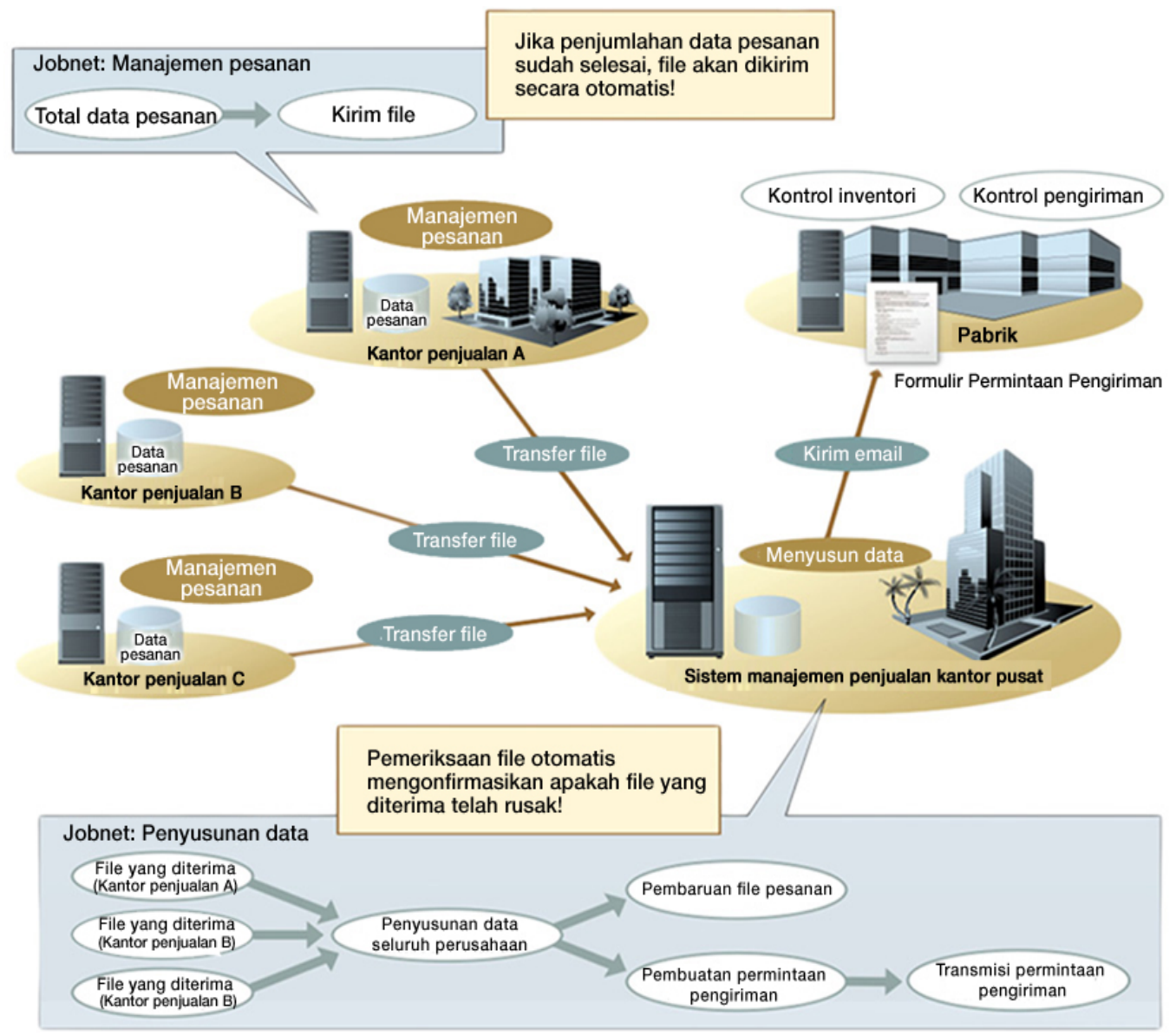

Gambar 1 Model Topologi TI di Perusahaan Hitachi (Hitachi di Indonesia, 2013)

Hitachi Asia telah menjadi integrator sistem terkemuka di regional sejak tahun 1995. Selain system-system yang disebutkan di atas, Hitachi unggul dalam menyediakan solusi, di antaranya Microsoft ERP, Infor ERP dan juga solusi Manajemen Rantai Pemasok berbasis web milik Hitachi yaitu Devo, Business Intelligence (BI) dan solusi CRM. Dan system - system tersebut merukan suatu modul aplikasi yang dimiliki oleh Hitachi, Ltd. untuk meningkatkan bisnisnya.

Pemanfaatan Data Warehouse dengan integrasi data adalah proses yang mengumpulkan data dengan cara yang membuatnya mudah dinavigasi. Bahkan dapat menemukan fakta-fakta dan angkaangka dari masa lalu tanpa harus melihat catatan keseluruhan. Sebuah Bisnis yang memiliki berbagai kebutuhan departemen integrasi data untuk kelancaran fungsi. Informatica PowerCenter membuat integrasi data lebih mudah dan membuatnya tersedia dalam cara yang lebih sederhana dan komprehensif

Penerapan teknologi informasi, tentunya memiliki dampak yang istimewa bagi para pekerja/staff dari Top, Middle hingga Low karyawan Hitachi, Ltd.. Dampak umumnya tentu saja intregasi antara divisi semakin terstruktur dan lebih rapi namun butuh waktu untuk mempelajari dan 
menyesuaikan diri dengan Modul Aplikasi yang di terapkan oleh perusahaan Hitachi karena untuk memanajemen data dalam jumlah besar harus memiliki system dan kinerja yang baik dari perushaan dan staff-staff yang berada di diperusahaan tersebut.

\section{PENUTUP}

Penggunaan Teknologi Informasi di perusahaan besar seperti Hitachi merupakan sesuatu yang sudah diwajibkan sebagai suatu media kesuksesan perusahaan. Cepatnya informasi, terpercayanya infromasi, memudahkan pekerjaan, dan mampu mengorganisir segala hal yang terdapat di Hitachi, Ltd. merupakan dampak besar yang dihasilkan teknologi infromasi untuk perusahaan.

Berbagai strategi bisnis teknologi infromasi yang diciptakan pun beraneka ragam, di antaranya aplikasi sistem ERP, SAP, P1/AJS Hitachi, bahkan menciptakan Hitachi Storage Data System menjadikan Hitachi, Ltd. perusahaan yang unggul dalam teknologi bisnis.

ERP sebagai perangkat lunak manajemen bisnis menghubungkan banyak komponen penggerak dari organisasi dengan menghadirkan fungsionalitas manajemen bisnis yang komprehensif, mulai dari sektor keuangan hingga rantai suplai. Meskipun itu memang ERP dinyatakan oleh perusahaan Hitachi, Ltd. masih memiliki kekurangan. Namun kekurangan tersebut dapat diatasi dengan baik.

JP1/AJS Hitachi sebagai salah satu solusi dalam TI nya, Hitachi dapat mengintegrasikan antar bagian sehingga dapat membuat tugas menjadi lebih sederhana terutama dalam menentukan tugas dan mengkoordinasikan pekerjaan antar bagian. Berbagai macam sistem aplikasi lainnya yang diterapkan oleh Hitachi, Ltd. memberikan dampak yang sangat besar bagi pertumbuhan bisnis Hitachi,Ltd.

\section{DAFTAR PUSTAKA}

Baden-Fuller, Charles. (1990). Managing Excess Capacity. New Jersey: Wiley-Blackwell.

Casadesus-Masanell, Ramon dan Ricart, Joan Enric. (2009). From Strategy to Business Models and to Tactics. Working Paper 10-036. Harvard: Hardvard Business School.

Hitachi di Indonesia. (2013). Solusi JP1/Automation Hitachi untuk Manajemen Pekerjaan. Diakses dari http://www.hitachi.co.id/products/case_studies/case_003/solution.html

O'Brien, James. (2005). Management Information Systems (10th ed.). New York: McGraw-Hill/Irwin.

Porter, Michael E. (1998). Competitive Strategy: Techniques for Analyzing Industries and Competitors. New York: Free Press.

Victor, Fred. (2010). Corporate strategy: sustaining strategic fit across culturally diverse supply chain relationships. Journal of Strategic Management, 1(2).

Ward, John dan Peppard, Joe. (2002). Strategic Planning for Information Systems. New Jersey: John Wiley and Sons. 